\title{
HOW PLANTS ARE NAMED
}

\section{by Keith F. Best, Regina Research Station, Regina}

"What's the common name of this plant" asks the visitor. To the inquirer's disappointment I sometimes must admit that it has no common name. Many books furnish common names only for those plants which are frequently encountered. Some texts attempt to give common names for all plants mentioned, but many of these are merely translations of the scientific names. People tend to avoid the scientific names. What a pity!

Linnaeus, in the 18th century, began the modern concept of naming plants by establishing the genera and species on a scientific basis. All plants are named under his binomial system. The botanical names are written in Latin, the chief language of science, which makes them understandable to all peoples in all languages.

The simplest names are termed monomials, such as "apple", "bean", "cat" or "Jones". When we wish to indicate a particular kind of plant or animal, we add another name such as "lima" bean, "Persian" cat or "Tom" Jones. Scientific names are constructed in a similar fashion but use a Latin terminology, placing the chief name first, with the modifying name following.

The first Latin name is that of the genus, a group of closely related species - like all the brothers and sisters in the Jones family (or the genus may contain only a single species - where Tom Jones was the first and last offspring of the Joneses). The genus or generic name is capitalized, whereas the species name which follows is not.

Scientific or botanical names are usually descriptive of the plant to which they are given and often help in studying the plant when the meaning is understood. The first or generic name is the accepted name of a group of plants all having certain similarities in their flowers, fruits, etc., while the specific names include all the different members of the group. As an example, Helianthus is the generic name for all of the sunflowers. Helianthus is from the Greek helios, the sun, and anthos, a flower, as the flowers follow the sun across the sky. Referring to a particular sunflower, we add a descriptive adjective. Then we have Helianthus annuus, which is the scientific name for "annual sunflower".

Many people, not accustomed to using these names, regard them as difficult and hard to recall. With use, they become as simple as the names of our friends or co-workers.

Generally, most botanical names are short and simple. When the scientific names are looked at without prejudice, they can be mastered with little difficulty. Many of the generic names have also become common or vernacular names such as "Alyssum" and "Petunia". Horticulturists and amateur gardeners accept such names as "Chrysanthemum", "Asparagus" and "Aster" without hesitation. When we wish to designate a particuar kind of aster, we add the species name, Aster multiflorus, meaning "many-flowered aster", or Aster oblongifolius which refers to the "oblong-leaved aster".

Different varieties within the same species are indicated by the addition of the varietal name, separated from the specific name by "var.", the abbreviation for the word "variety". As an example, botanists write Lilium philadelphicum var. andinum to indicate that our Western Red Lily is only a variety of the wood lily.

When exact scientific identification of a plant species is required, the name of the person who first named the plant (or an abbreviation of that scientist's name) is added to the generic and specific names. We would then write Lilium philadelphicum L. var. andinum (Nutt.) Ker.

Common names vary from place to 
place and may even change with time. Common names also lack precision, a fact which often limits their usefulness. Sometimes they are confusing and misleading. We know that African violets, for instance, are not true violets, that pepper-grass is not a grass and that sow-thistle is not a true thistle. Canada thistle is a weedy invader from Europe and the same plant in New Zealand is tagged as California thistle.

It is indeed a good idea to be familiar with the scientific names of plants.

\title{
1971 BOTANICAL RECORDS FOR SASKATCHEWAN
}

\author{
by John H. Hudson, 103 Richmond Crescent, Saskatoon
}

The 1971 collecting season produced the best harvest of novelties for me since 1958. Here are reported two plants new to Canada, two new to Saskatchewan alone, and three seldom mentioned varieties.

Of the plants new to Canada perhaps the most interesting is Salsola collina, Pall. I collected it as \#2749 on August 17, 1971 at Estevan, "C.N.R. tracks, soil cindery and very drouthy, abundant." A couple of weeks later, back in Saskatoon, I visited the downtown C.N.R. yards to see how Eragrostis poaeoides as reported by Hudson (1971) was surviving (very nicely, thank you) and found more Salsola collina, collection \#2754 of September 3, 1971, "downtown C.N.R. yards west of 600 block 1st Avenue, soil dry and cindery." This plant, in the same genus with ordinary Russian Thistle, appears as a less branchy, more erect, version of the famous weed with a hint of Kochia about the flowers. Technically, the mature calyx lacks the horizontal wing so prominent in Salsola kali, while the inflorescence tends to be in terminal inconspicuously bracted spikes. In Russian Thistle axillary flowers are numerous, while such flowers as are in terminal spikes are conspicuously bracted with the noxious prickles. One gathers Salsola collina is little of a tumbleweed; on a railroad embankment in L.S.D. 3 of 31-1-VI W2nd, 3 mi. E. of Roche Percee, on May 3, 1971, I had found a plant described in my notes as "a dead Goosefoot Family annual I don't know, like Salsola but not quite so spiny, and with tough, not shattering, stems." When in August I got back to the site, the next generation of these annuals turned out to be $S$. collina.

This Salsola collina, a native of Soviet Middle Asia, was reported in Minnesota by Pohl and Gillespie (1959). Then Stevens (1961) reported it for North Dakota, with collections going back to 1949 . It is also keyed and mapped for Montana by Booth and Wright (1966). It is not in Boivin (1966) so presumably is new to Canada. This one seems to be spread-. ing largely by rail - I have not yet seen it away from railroad tracks.

A hitherto unreported desert shrub for Canada is what I have taken to be Suaeda intermedia S. Wats., collected as \#2762 on September 23, 1971 on "bare exposed S-facing outcrops and crags of 'Redeposited Ravenscrag' formation on NE1/4 211-X W3rd, alt. 3000'." This plant looked much like a small Greasewood, with terete fleshy leaves, but these distributed all around the unbranched and brittle shoots of the year which radiate in every direction from the woody base. Flowers and fruit were poorly displayed due to the lateness of the collection (and the dryness of the summer?); no seed appeared to have been set, but the flowers seemed to have been in axillary glomerules scattered towards the ends of these shoots of the year. Boivin (1968) weighed a Hitchcock (1964) report from Alberta and found it wanting, so presumably this is new to Canada.

The habitat of this shrub is very 